\title{
Strategi Dosen Dalam Manajemen E-Learning Guna Meningkatkan Hasil Belajar Mahasiswa di Perguruan Tinggi
}

\author{
Nisak Ruwah Ibnatur Husnul \\ Universitas Pamulang \\ nissaqlecturer@gmail.com \\ Aris Suharyadi \\ Universitas Negeri Yogyakarta \\ arisuharyadi@uny.ac.id
}

\begin{abstract}
The purpose of this research is to find out how lecturers' strategies in e-learning management to improve learning outcomes in college. In this study, strategi lecturer in e-learning management in question includes how to plan, implement, supervise, and evaluate in online learning (e-learning). This type of research uses a qualitative approach with descriptive methods. The subjects of the study are lecturers who do online learning and are able to improve the results of learning through e-learning. The research instrument uses interview guidelines and documentation. The data collection technique in this study is an interview with a strengthened on website e-learning display website documentation. Data analysis using data triangulation techniques. The results of this study showed that the lecturer's strategy in managing e-learning, including 1) Planning, namely drawing up a learning plan on the $e$ learning website, with a sub-view of RPS (lesson plan), learning achievements, diagnostic tests (pre-test), module materials, learning videos, journal links related to materials, discussion forums, tasks, and absorption tests (posttest). 3) Supervision is by utilizing the agreed e-learning time, monitoring process through zoom media, video conference and whatsapp group to know the activeness and atamodity of students in e-learning. 4) Evaluation, with diagnostic tests and absorption tests as an indicator of student atteanity in receiving elearning materials and independent tasks to improve HOTS (higher order of thinking skills) students. Evaluation in maximizing e-learning content in the website is done with CIPP (context, input, process, and output) so that innovation from lecturers is always increasing.
\end{abstract}

Keywords: Lecturers, E-Learning, Management, Universities, Strategy

\section{Article Info}

\section{PENDAHULUAN}

Perkembangan sektor pendidikan pada suatu negara merupakan salah satu indikator kemajuan dari bangsa tersebut. Perubahan dan perkembangan perilaku seseorang dapat dilakukan melalui pola pendidikan yang dilakukan dengan sengaja, teratur, dan berencana. Menurut Crow and Crow dalam Suharno (2018) mengatakan bahwa "Pendidikan tidak hanya dipandang sebagai sarana untuk persiapan hidup yang akan datang, tetapi juga untuk kehidupan sekarang yang dialami individu dalam perkembangannya menuju tingkat kedewasaan. Salah satu upaya 
yang bisa dilakukan untuk memajukan pendidikan adalah dengan melakukan inovasi pembelajaran".

Terkait dengan inovasi pembelajaran tidak terlepas dari pemanfaatan teknologi yang semakin meningkat di era revolusi industry 4.0. Salah satu upaya untuk melakukan inovasi pembelajaran yang efektif dan efisien adalah menggunakan perangkat teknologi informasi dan komunikasi. Hal tersebut menjadi penting mengingat ketika kegiatan pembelajaran inilah transfer berbagai ilmu dan kompetensi berjalan. Menteri Riset Teknologi dan Pendidikan Tinggi (2018) Prof. H. Mohamad Nasir, Ph.D., Ak. mengatakan bahwa "Dalam menghadapi era Revolusi Industri 4.0, pemerintah akan mendorong penggunaan metode e-learning dalam sistem pembelajaran di perguruan tinggi. Kebijakan tersebut menjadi inovasi terbaru dari pemerintah dalam bidang pendidikan. Pemerintah akan menawarkan 3 opsi untuk kebijakan metode pembelajaran bagi perguruan tinggi yaitu metode konvensional face to face, blanded learning (menggunakan metode face to face dan e-learning), dan e-learning".

E-learning adalah proses pembelajaran yang menggunakan teknologi internet. Dengan internet, proses pembelajaran tidak selalu harus di dalam ruang kelas. Terdapat beberapa kelebihan yang diperoleh ketika menggunakan e-learning. Misalnya mahasiswa bisa berkreasi sekaligus berinovasi untuk memilih metode, sumber, dan media untuk belajar. Efisien dalam segi biaya karena tidak perlu gedung yang otomatis tidak ada anggaran untuk biaya trasnportasi. Fleksibel dalam tempat, waktu, dan jarak. Bagi mahasiswa yang sudah bekerja, e-learning menjadi solusi terbaik karena sangat dimungkinkan untuk menyesuaikan dengan keadaan.

(Ghirardini, 2011) mengatakan bahwa "E-learning can be defined as the use of computer and Internet technologies to deliver a broad array of solutions to enable learning and improve performance." Artinya e-learning didefinisikan sebagai penggunaan komputer dan teknologi internet untuk memberikan fasilitas yang luas sebagai solusi dalam pembelajaran untuk meningkatkan kinerja. Hal ini juga merupakan solusi untuk mahasiswa yang secara geografis berdomisili jauh dari kampus, karena keterbatasan waktu atau sumber daya untuk berpergian. Sejalan dengan Blackwell, Lauricella \& Wartella (2016), menambahkan bahwa "e-learning adalah proses instruksi yang melibatkan penggunaan peralatan elektronik (komputer dan media telekomunikasi) dalam menciptakan, membantu perkembangan, menyampaikan, menilai, dan memudahkan suatu proses belajar mengajar dimana pelajar sebagai pusatnya serta dilakukan secara interaktif kapan saja dan dimana saja". Penggunaan $e$-learning memiliki keuntungan yaitu mahasiswa tidak perlu datang ke kampus untuk kuliah, cukup dengan bantuan akses internet dapat belajar di mana saja dan kapan saja.

Berdasarkan beberapa keunggulan penggunaan e-learning di atas, ternyata belum seluruh kampus di Indonesia mau dan mampu untuk menggunakannya. Salah satu pendapat dari Pannen, Paulina (2014) berpendapat bahwa penerapan e-learning pada mayoritas kampus di Indonesia belum terisiniasi secara sistematis karena hanya 600 dari 3600 yang menerapkan metode e-learning. Sementara untuk mata kuliahnya masih sekitar 2000 lebih dengan sekitar 30 program studi yang sudah menerapkan e-learning. Selayaknya melihat kondisi Indonesia saat ini, apalagi dimasa pandemi maka seluruh kampus idealnya menggunakan e-learning .

Bersamaan dengan situasi pandemi yang hingga saat ini belum diketahui kapan akan berakhir maka pembelajaran jarak jauh menggunakan e-learning merupakan suatu kewajiban agar seluruh peserta didik tetap bisa mendapatkan layanan pendidikan. Sayangnya, mayoritas mahasiswa di Indonesia belum dapat belajar secara mandiri sehingga pembelajaran 
jarak jauh belum optimal dilakukan. Di satu sisi pemerintah telah menunjuk Universitas Terbuka (UT) untuk menjadi kampus yang menerapkan perkuliahan secara e-learning dan pada tahun 2022 UT bermaksud meningkatkan angka partisipasi kasar perguruan tinggi yang kini 31,5 menjadi 40 persen, hal tersebut sekaligus untuk menyesuaikan dengan era revolusi industri 4.0. Salah satu strateginya adalah dengan memastikan pendidikan jarak jauh, terutama pembelajaran dalam jaringan terselenggara dengan baik.

Dengan begitu artinya, pada masa pandemi covid-19 ini UT seharusnya bisa menjadi role model kampus-kampus lainnya dalam melaksanakan pembelajaran jarak jauh yang efisien. Kendala yang menjadi prioritas dalam sistem pembelajaran e-learning adalah penyiapan acces point, serta literasi komputer dan internet yang harus ditingkatkan. Berdasarkan hal itu maka pembelajaran $e$ learning tentu harus melihat keadaan sebenarnya di lapangan mengenai kesiapan hardware maupun brainware.

Selain UT, ada pula perguruan tinggi swasta yang menjadi pelopor perkuliahan jarak jauh. Sebelum pandemi covid ini terjadi, kampus ini telah menyelenggarakan perkuliahan daring yang bisa dikatakan berhasil. Perguruan tinggi tersebut adalah Universitas Bina Nusantara (Binus) yang menerapkan metode pembelajaran e-learning yang diberi nama Binus Online Learning. Mayoritas perkuliahan dilakukan secara daring sehingga mahasiswa tidak perlu hadir di kampus. Metode tersebut "Mendorong mahasiswa untuk self learning, untuk belajar mandiri," ujar Deputi Direktur Binus online learning, Agus Putranto (2014). Agus mengatakan lagi bahwa "Binus Online Learning merupakan suatu metode pembelajaran yang mulai diterapkan sejak 14 Februari 2009. Metode tersebut biasanya dimanfaatkan oleh mahasiswa yang sudah bekerja, ibu rumah tangga, atau orang yang 36 memiliki kesibukan lain sehingga tidak memiliki waktu jika harus hadir tatap muka langsung di kampus". Binus sudah merancang sedemikian rupa pola pembelajaran secara online sehingga mahasiswa tetap merasa sedang belajar di dalam kelas. Pada metode tersebut mahasiswa dapat berinteraksi dengan dosen dan anggota kelas lainnya melalui forum diskusi yang sudah disediakan. Metode kuliah semacam ini sangat dituntut dalam situasi pandemi saat ini.

Kampus lain yang juga mengikuti jejak UT dan Binus dalam menerapkan e-learning adalah Universitas Pamulang (UNPAM). Sebagai satu diantara banyaknya kampus swasta yang terbilang baru, UNPAM pun berusaha mensinergikan teknologi ke dalam perkuliahan melalui sistem pembelajaran berbasis e-learning. Model pembelajaran yang terus mengalami perkembangan teknologi membuat UNPAM berupaya menerjemahkan itu melalui pola perkuliahan berbasis e-learning (Dayat Hidayat, 2015). Walaupun Pola $e$ learning yang dikembangkan oleh UNPAM bukan e-learning yang mengambil konsep sistem perkuliahan jarak jauh. Melainkan $e$ learning dipakai apabila ada pertemuan perkuliahan konvensional belum maksimal. Namun pada saat ini tentu fokusnya dapat bergeser ke sepenuhnya daring, mengingat kondisi pandemi covid-19.

Selain tiga perguruan tinggi di atas, masih banyak lagi perguruan tinggi yang mefasilitasi e-learning sebagai pembelajaran saat ini. Naidu dalam Abiola, et al (2015) mengatakan "E-learning is the intentional use of networked information and communications technology in teaching and learning." Artinya bahwa e-learning merupakan penggunaan teknologi informasi dan komunikasi jaringan dalam pengajaran dan pembelajaran. $E$ learning merupakan pembelajaran jarak jauh yang menggunakan teknologi komputer atau biasanya disebut internet. Jethro, et al (2012) mengatakan bahwa "E-learning is the use of 
Internet technologies to enhance knowledge and performance." Artinya bahwa e-learning mengacu pada penggunaan teknologi Internet untuk memberikan beragam solusi yang meningkatkan pengetahuan dan kinerja. Inovasi dalam teknologi e-learning mengarah pada sebuah revolusi dalam pendidikan, memungkinkan pembelajaran menjadi individual (adaptive learning), meningkatkan interaksi peserta didik dengan orang lain (collaborative learning), dan mengubah peran dosen.

Peran dosen disini menjadi semakin berat, karena selain menguasai materi seperti biasa, namun harus melek teknologi juga. Permasalahan lain ketika e-learning sudah berjalan adalah bagaimana hasil dari e-learning tersebut. Harapannya dengan pembelajaran online tidak akan menurunkan hasil belajar mahasiswa. Oleh karena itu, perguruan tinggi yang menerapkan e-learning harus mampu mendistribusikan melalui dosen pengampu untuk mampu berinovasi dalam e-learning tersebut. Adanya perubahan tatap muka menjadi e-learning tentu akan signifikan oleh mahasiswa, dengan demikian hasil belajar menjadi sorotan untuk tetap dipertahankan tidak jauh dari hasil belajar tatap muka.

Dalam hal ini integrasi e-learning ke dalam pendidikan dapat mengkatalisis pergeseran penerapan teori pembelajaran orang dewasa, dimana pendidik tidak lagi melayani terutama sebagai distributor konten, namun akan menjadi lebih terlibat sebagai fasilitator pembelajaran dan asesor kompetensi. Para dosen harus mampu mengembangkan suatu metode baru dalam e-learning guna menarik mahasiswa dalam belajar dan memahami materi dengan baik. Dosen dituntut untuk mampu berinovasi dalam menciptakan $e$ learning supaya dapat meningkatkan hasil belajar mahasiswa.

Sejalan dengan Menteri Riset, Teknologi, dan Pendidikan Tinggi (Menristekdikti) Mohamad Nasir (2019), mengatakan bahwa "Melihat e-learning merupakan salah terobosan untuk menaikan Angka Partisipasi Kasar (APK) pendidikan tinggi Indonesia yang saat ini berada di angka 34,58 persen". Menristekdikti (2019) menyampaikan kembali " Sistem pembelajaran secara e-learning harus diimbangi dengan peningkatan kompetensi dosen. Mahasiswa yang dihadapi dosen saat ini adalah mahasiswa generasi milenial dan generasi $\mathrm{Z}$, oleh karena itu dosen harus meningkatkan kompetensi keilmuan serta melakukan inovasi metode pembelajaran".

Berkaitan dengan pemaparan di atas, $e$ learning menurut Clark, R. C., \& Mayer (2003) didefinisikan sebagai "Instruction delivered on computer by way of CD-ROM, internet, or intranet with the following features: 1) includes content relevant to the learning objectives, 2) uses instructional methods such as examples and practice to help learning, 3) uses media elements such as words and pictures to deliver the content and methods, and 4) builds new knowledge and skills linked to individual learning goals or to improve organizational performance".

Koswara (2016) dalam pemaparannya mengenai peran dosen adalah "Kemampuan baru yang diperlukan dosen untuk e-learning, antara lain perlu mengerti tentang e-learning, mengidentifikasi karakteristik mahasiswa, mendesain dan mengembangkan materi kuliah yang interaktif sesuai dengan perkembangan teknologi baru, mengadaptasi strategi mengajar untuk menyampaikan materi secara elektronik, mengorganisir materi dalam format yang mudah untuk dipelajari, melakukan training dan praktek secara elektronik, serta dosen idealnya terlibat dalam perencanaan, pengembangan, dan pengambilan keputusan. Terakhir yang tidak kalah penting adalah dosen wajib mengevaluasi keberhasilan pembelajaran, attitude dan persepsi para mahasiswanya. 
Hal ini berkorelasi dengan rumusan masalah dalam penelitian ini adalah mengenai bagaimana seorang dosen dalam merumuskan strategi manajemen dalam e-learning untuk meningkatkan hasil belajar mahasiswa, dari proses perencanaan, pelaksanaan, pengawasan dan evaluasi dosen. Mengenai e-learning ini sudah lama berjalan, tentu banyak dosen-dosen yang mempunyai kompetensi dalam metode pembelajaran efektif yang ditawarkan oleh dosen. Adapun tujuan dari penelitian ini adalah untuk mengetahui strategi manajemen $e$ learning dosen yang meliputi perencanaan, pelaksanaan, pengawasan dan evaluasi dalam e-learning untuk meningkatkan hasil belajar mahasiswa di perguruan tinggi.

Tingkat keberhasilan suatu pembelajaran dapat diidentifikasi melalui perilaku dosen dan mahasiswanya ketika sedang berada di ruang kelas atau konteks lingkungan di mana proses pembelajaran berlangsung. Perilaku-perilaku dosen ini diasumsikan sebagai perilaku umum, yang mencakup kecepatan, balikan, dan pemberian contoh. Berbeda dengan pengajaran dalam strategi spesifik, mahasiswa menganggap bahwa tingkat pengajaran berkaitan dengan perilaku umum (dosen) yang dipakai dalam pembelajaran keterampilan dasar. Mahasiswa secara relatif menganggap bahwa beberapa perilaku umum (dosen) berhubungan dengan hasil belajar yang lebih tinggi (toleransi untuk respon yang beraneka ragam, menekankan proses daripada produk, dan kesempatan untuk berpikir pada tingkat yang lebih tinggi.

\section{METODE PENELITIAN}

Berdasarkan penjelasan permasalahan dan tujuan di atas, maka metode penelitian dijabarkan sebagai berikut ini :

\section{Jenis Penelitian}

Jenis penelitian ini menggunakan pendekatan kualitatif deskriptif. Menurut Sugiyono (2017), memaparkan dalam bukunya "Metode penelitian kualitatif adalah metode 38 penelitian yang berlandaskan pada filsafat postpositivisme atau enterpretatif, yang mana digunakan untuk meneliti kondisi obyek yang alamiah dan peneliti adalah instrumen kunci". Dalam hal ini akan menjelaskan mengenai strategi manajemen dosen dalam e-learning untuk meningkatkan hasil belajar di perguruan tinggi.

\section{Subjek Penelitian}

Subjek penelitian menurut Suharsimi , A (2016) yaitu "memberi batasan subjek penelitian sebagai benda, hal atau orang dimana tempat data untuk variable penelitian melekat, dan yang di permasalahkan. Dalam sebuah penelitian, subjek penelitian mempunyai peran yang sangat strategis karena pada subjek penelitian itulah data tentang variabel yang akan di amati". Subjek dalam penelitian ini adalah dosen-dosen yang sudah melaksanakan e-learning selama 3 tahun di perguruan tinggi yang mengadakan blended learning. Adapun dosen-dosen terangkum sebagai berikut :

Tabel 1. Subjek Penelitian

\begin{tabular}{cc}
\hline No. & Dosen (Perguruan Tinggi) \\
\hline 1 & Dosen Universitas Pamulang \\
\hline 2 & Dosen Universitas Bina Nusantara \\
\hline 3 & Dosen Universitas Negeri Yogyakarta \\
\hline
\end{tabular}

\section{Teknik Pengambilan Data}

Teknik pengambilan data pada riset ini adalah melalui observasi, survey dan wawancara dengan subjek penelitian. Observasi dan survey diadakan awal pada saat diskusi mengenai konten dari website elearning. Namun dalam penelitian ini lebih difokuskan pada wawancara mendalam dengan subjek penelitian mengenai proses perencanaan, pelaksanaan, pengawasan dan evaluasi dari dosen dalam e-learning untuk meningkatkan hasil belajar mahasiswa di perguruan tinggi.

Menururut Esterbers dikutip Sugiyono (2017) menyatakan bahwa "interview is a meeting of two persons to exchange 66 information and idea trough question and 
responses, resulting in communication and joint construction of meaning abaout a particular topic". Wawancara dapat dimaknai sebagai pertemuan dua orang untuk bertukar informasi dan ide melalui tanya jawab, sehingga dapat dikonstruksikan makna dalam suatu topik tertentu. Dalam penelitian ini wawancara yang digunakan adalah wawancara secara mendalam dengan jenis wawancara terstruktur.

\section{Teknik Analisis Data}

Menurut Sugiyono (2012) "Analisis data adalah proses mencari dan menyusun secara sistematis data yang diperoleh dari hasil wawancara, catatan lapangan dan dokumentasi dengan mengorganisasikan data dalam katagori, menjabarkan kedalam unit-unit, melakukan sintesa, menyusun ke dalam pola, memilih mana yang penting dan yang mana yang dipelajari, dan membuat kesimpulan sehingga mudah dipahami oleh diri sendiri maupun orang lain”. Adapun langkah-langkah untuk menganalisis data dalam penelitian ini adalah:

\section{Data Reduction (Reduksi Data)}

Data yang jumlahnya cukup banyak perlu dicatat secara teliti dan rinci. Semakin lama waktu penelitian dilakukan maka jumlah datanyapun semakin banyak, kompleks dan rumit. Berdasarkan hal itu maka perlu segera dilakukan kegiatan merangkum, memilih hal-hal yang pokok, memfokuskan pada hal-hal yang pokok yang penting, mencari tema dan polanya, dan membuang yang tidak perlu. Kegiatan tersebut dapat membuat data yang telah direduksi akan memberikan gambaran yang lebih jelas serta proses pencarinya mudah bila diperlukan.

\section{Data Display (Penyajian data)}

Setelah melakukan reduksi data maka langkah selanjutnya adalah penyajian data. Dalam penelitian kualitatif, penyajian data bisa dilakukan dalam katagori uraian singkat, bagan, hubungan antar katagori, flowchart dan sejenisnya. Dalam hal ini,
Miles dan Huberman (Sugiyono., 2012) menyatakan "the most frequent form of display data for qualitative research data in the past has been narrative tex". Yang paling sering digunakan untuk menyajikan data dalam penelitian kualitatif adalah dengan teks yang bersifat naratif.

\section{Conclusion} Drawing/Verivication

\section{(Kesimpulan dan Verifikasi)}

Langkah ketiga dalam analisis data menurut Miles dan Huberman (Sugiyono., 2012) adalah "Penarikan kesimpulan dan verifikasi. Kesimpulan awal yang dikemukakan masih bersifat sementara, dan akan berubah bila tidak ditemukan buktibukti yang kuat yang mendukung pada tahap pengumpulan data berikutnya". Tetapi apabila kesimpulan yang dikemukakan pada tahap awal, didukung oleh bukti-bukti yang valid dan konsisten saat peneliti kembali ke lapangan mengumpulkan data, maka kesimpulan yang dikemukakan merupakan kesimpulan yang kredibel.

\section{HASIL DAN PEMBAHASAN}

Di era revolusi industry 4.0, perguruan tinggi diharapkan dapat menyesuaikan proses perkuliahannya dengan perkembangan teknologi terkini. Salah satu yang menjadi fokus utamanya adalah dengan meningkatkan kualifikasi dan kompetensi para dosennya agar mampu bersaing di kelas internasional. Proses pembelajaran secara daring (e-learning) telah dilakukan di berbagai perguruan tinggi Indonesia, harapan selanjutnya akan jauh lebih banyak perguruan tinggi yang mengadopsi sistem ini. E-learning menjadi salah satu metode yang pembelajaran jarak jauh yang harus bisa diciptakan secara menarik, agar sasaran pendidikan yaitu mahasiswa mampu menyerap materi dengan baik seperti pada saat tatap muka. Berdasarkan data yang sudah diambil selama satu tahun atau dua semester, maka di dapat strategi manajemen dosen, dari proses perencanaan, pelaksanaan, pengawasan 
dan evaluasi dalam e-learning untuk meningkatkan hasil belajar siswa di perguruan tinggi adalah sebagai berikut:

Perencanaan

Pada kegiatan ini, pendidik merencanakan kegiatan yang akan dilakukan diawali dengan penentuan tujuan pembelajaran. Tujuan dalam hal ini adalah yang ingin dicapai setelah terjadinya proses pembelajaran. Pembelajaran adalah proses yang terdiri dari apa yang dilakukan peserta didik dan apa yang dilakukan pendidik. Oleh karena itu, untuk mendapatkan proses pembelajaran yang berkualitas dan maksimal, maka dibutuhkan adanya perencanaan.

Perencanaan pembelajaran merupakan kegiatan pengambilan keputusan berdasarkan hasil berpikir secara rasional. Hal itu dapat mengenai sasaran dan tujuan pembelajaran tertentu, perubahan tingkah laku peserta didik setelah melalui pembelajaran serta upaya yang harus dilakukan dalam mencapai tujuan tersebut. Konkretnya, dalam perencanaan pembelajaran ini pendidik membuat perangkat pembelajaran. Perangkat pembelajaran dalam perguruan tinggi yang harus dibuat oleh dosen juga mampu diterapkan dalam e-learning. Adanya inovasi dan perningkatan pada perangkat pembelajaran tatap muka ke $e$ learning harus serta merta dibedakan, supaya jelas sasarannya terhadap mahasiswa.

Menurut Nisak dan Heri (2017), mengatakan dalam penelitiannya bahwa "Guru juga membuat seperangkat pembelajaran yang digunakan untuk pedoman guru dalam proses mengajar, seperangkat pembelajaran merupakan arah dan tujuan yang ingin di capai, dengan menjelaskan materi-materi secara keseluruhan selama satu semester agar siswa mempersiapkan mental dan materi yang akan di ampu selama satu semester." Begitu juga dengan dosen sebagai pengajar dalam hal ini, harus membuat rencana pembelajaran $e$ learning, capaian pembelajaran dan materi selama satu semester.

40
Dosen dalam merencanakan pembelajaran online (e-learning) harus memenuhi kriteria dalam daya tarik terhadap mahasiswa. Ada beberapa hal yang harus diperhatikan dalam menyusun konten atau fitur dalam website e-learning. Tampilan awal dalam website dengan memperkenalkan dosen pengampu, dari nama, no HP, email dan lainlain disesuaikan dengan kebutuhan, kemudian dilengkapi dengan: Deskripsi Kuliah, Pokok Bahasan Materi, Capaian Pembelajaran, dan Rencana Pembelajaran Semester (RPS). Dalam penyusunan di website pun, harus diatur secara rapi dan menarik, supaya mahasiswa ketika diperkenankan untuk e-learning selama satu semester tidak akan bosan dalam belajar dari materi tersebut. Adapun tampilan yang berhasil dijadikan sebagai contoh untuk meningkatkan minat belajar supaya ketercapaian belajar mahasiswa meningkat adalah sebagai berikut:

Kemudian pada tampilan materi per pertemuan di e-learning, dilengkapi dengan fitur-fitur berikut ini :

1. Capaian Pembelajaran

Pada fitur ini berisikan capaian pembelajaran yang harus mahasiswa pahami setelah menerima materi dari modul dan video. Dengan adanya capaian pembelajaran, mahasiswa akan mengetahui apa saja tujuan dari materi tersebut dan bisa focus terhadap capaian pembelajaran. Dosen harus mampu mendeskripsikan dengan jelas capaian pembelajaran dengan menyesuaikan materi per babnya.

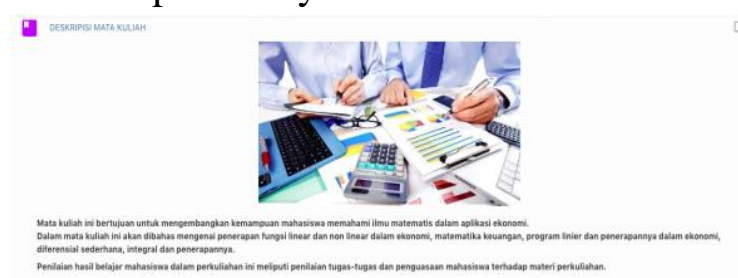

Gambar 1. Deskripsi Mata Kuliah 


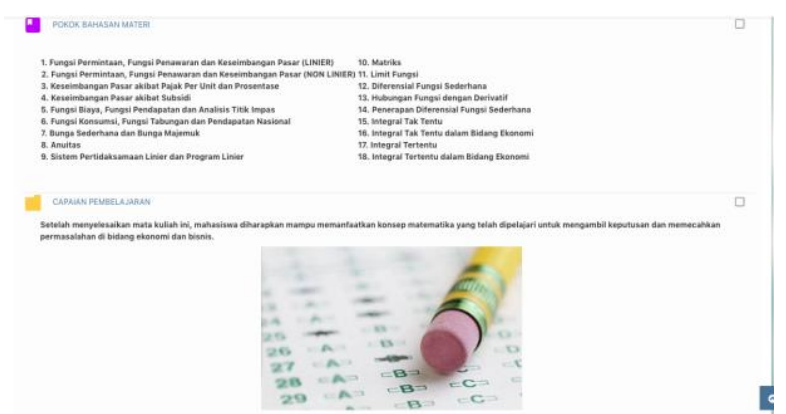

Gambar 2. Pokok Bahasan Materi dan Capaian Pembelajaran

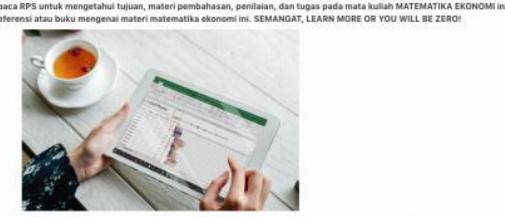

Gambar 3. Rencana Pembelajaran Semester (RPS)

\section{Tes Diagnostik}

Tes Diagnostik ini adalah tes untuk mengetahui kemampuan awal mahasiswa sebelum menerima materi yang diberikan dosen. Istilah nya sama dengan pre-test yaitu sebagai bahan untuk evaluasi dosen dalam mengukur kemampuan mahasiswa sebelum memahami materi, sehingga bisa menjadi tolak ukur atas ketercapaian mahasiswa tersebut.

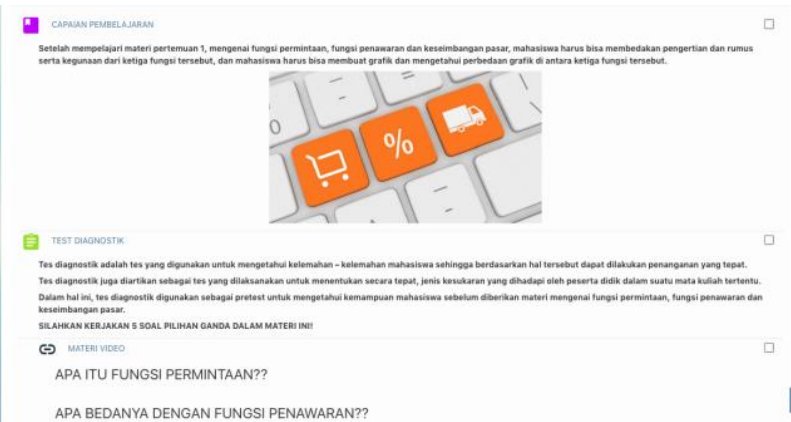

Gambar 4. Capaian Pembelajaran dan Tes Diagnostik

3. Video Pembelajaran : Materi Pengantar Dalam fitur video ini menjadi daya tarik tersendiri untuk mahasiswa, karena menjadi media visual sebagai pengganti tatap muka. Oleh karena itu, dosen dituntut untuk mampu membuat video untuk memperkuat materi yang disampaikan melalui e-learning. Video yang dibuat juga tidak boleh berdurasi panjang, karena akan menjadi monoton dan membosankan. Video ini difokuskan sebagai pengantar materi, sebelum mahasiswa membaca modul.

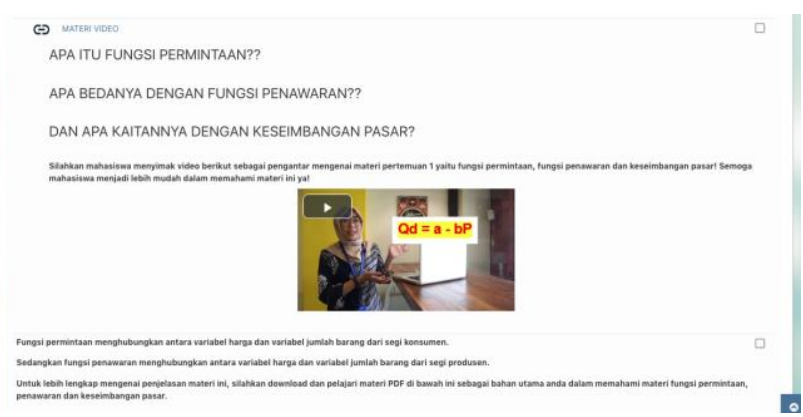

Gambar 5. Materi Video

\section{Materi (Modul)}

Fitur ini menjadi materi inti secara keseluruhan mengenai bab atau tema yang akan dipelajari mahasiswa. Modul disesuaikan dengan kebutuhan dan karakteristik setiap perguruan tinggi. Materi disusun sedemikian untuk memudahkan mahasiswa dalam mempelajari secara $e$ learning.

5. Pranata Luar (Berita atau Opini terkait Materi)

Ini adalah fitur tambahan untuk menguatkan materi mengenai implementasi materi yang berkaitan dengan kehidupan sehari-hari. Dengan harapan pada pranata luar ini akan memudahkan mahasiswa dalam mengimplementasikan materi sehingga pemahaman akan melekat dalam diri mahasiswa.

6. Tautan Eksternal (Jurnal terkait Materi)

Pada tautan eskternal ini berisikan jurnal yang berkorelasi dengan materi. Kelebihan dalam fitur ini adalah, mahasiswa bisa membaca tulisan-tulisan dosen sehingga kebermanfaatan dari jurnal kita bisa dinikmati oleh mahasiswa sendiri. Kelebihan yang lain adalah mahasiswa menjadi paham mengenai materi yang dimuat dalam jurnal sebagai data dan fungsi tujuan dalam suatu penelitian. 


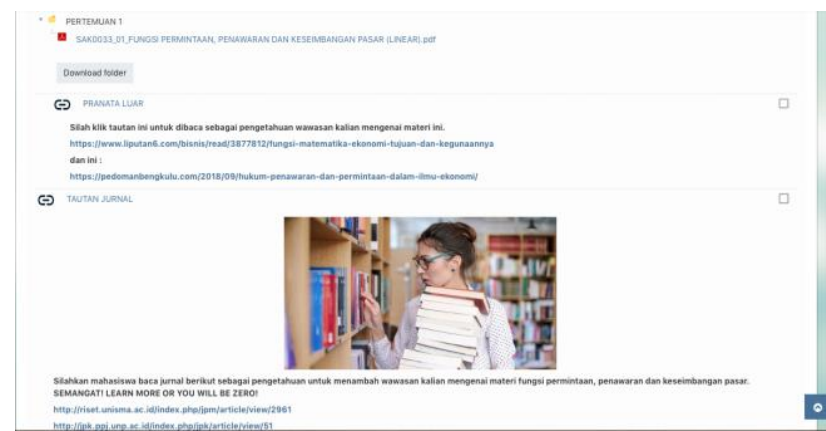

Gambar 6. Contoh Tautan Eksternal

\section{Forum Diskusi}

Forum diskusi ini menjadi forum yang ditunggu-tunggu oleh mahasiswa, karena sebagai bahan untuk diskusi dan menuangkan pendapat mengenai permasalahan yang tidak dipahami dari materi. Peran dosen disini dituntut untuk menjadi fasilitator dalam berdiskusi, bisa menjadi moderator diskusi dan mengawasi jalannya diskusi ketika mahasiswa saling berpendapat dan berargumen, sehingga dosen juga nanti akan memerankan perannya sebagai pengajar dalam forum diskusi tersebut.

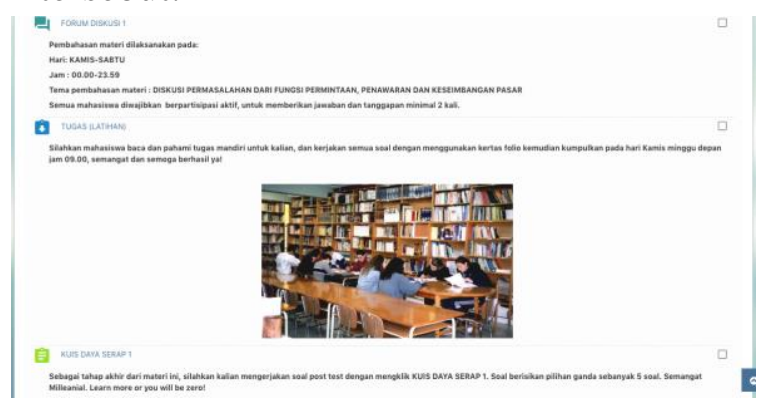

Gambar 7. Contoh Forum Diskusi

\section{Tugas Mandiri}

Fitur tugas mandiri ini adalah untuk memberikan tugas mandiri terkait dengan materi yang sudah dijelaskan dan dipahami dalam e-learning. Ini menjadi penilaian dosen sendiri dalam mengetahui kemampuan mahasiswa dalam menguasai materi. Tugas ini dibuat dengan soal terbuka yang menuntut higher order thinking skill (HOTS) mahasiswa.

9. Kuis Daya Serap

Ini adalah fitur terakhir mahasiswa dalam e-learning, yaitu kuis daya serap.
Kuis daya serap ini disusun sebagai post test, untuk mengetahui ketercapaian mahasiswa setelah melihat dan menyimak video, mempelajari materi dan berdiskusi.

Berdasarkan beberapa gambar dan penjelasan fitur desain di atas, maka dosen bisa bekerja sama dengan dosen lain yang mengampu mata kuliah yang sama, sehingga dalam menyusun perangkat pembelajaran online (e-learning) bisa menyamakan persepsi dalam mata kuliah yang akan di ajarkan. Adanya koordinasi yang baik sesame dosen pengampu mata kuliah, akan memudahkan dalam membuat rencana pembelajaran yang baik dan inovatif. Hal ini sejalan dengan Robbins \& Coulter (Hasanah, Yenny M. \& Husnul, 2019) yang mendefinisikan bahwa "perencanaan sebagai sebuah proses yang ditandai dari penetapan tujuan organisasi, menentukan strategi untuk pencapaian tujuan organisasi tersebut secara menyeluruh, serta merumuskan sistem perencanaan yang menyeluruh untuk mengintegrasikan dan mengoordinasikan seluruh pekerjaan organisasi hingga tercapainya tujuan organisasi”. Planning is a process that involves defining the organization's goals, establishing an overall strategy for achieving those goals, and developing a comprehensive set of plans to integrate and coordinate organizational work.

\section{Pelaksanaan}

Menurut George R. Terry (Sukarna, 2011) mengatakan bahwa "Actuating is setting all members of the group to want to achieve and to strike to achieve the objective willingly and keeping with the managerial planning and organizing efforts". Artinya pelaksanaan adalah membangkitkan dan mendorong semua anggota kelompok agar supaya berkehendak dan berusaha dengan keras untuk mencapai tujuan dengan ikhlas serta serasi dengan perencanaan dan usaha-usaha pengorganisasian 
dari pihak pimpinan. Definisi di atas terlihat bahwa tercapai atau tidaknya tujuan tergantung kepada bergerak atau tidaknya seluruh anggota kelompok manajemen, mulai dari tingkat atas, menengah sampai ke bawah. Segala kegiatan harus terarah kepada sasarannya, mengingat kegiatan yang tidak terarah kepada sasarannya hanyalah merupakan pemborosan terhadap tenaga kerja, uang, waktu dan materi atau dengan kata lain merupakan pemborosan terhadap tools of management.

Berkaitan dengan teori di atas, maka setelah dosen mendesain website e-learning pada proses perencanaan secara baik, maka tugas berikutnya adalah pelaksanaan untuk diterapkan kepada mahasiswa. Sebaik apapun sistem yang dibangun ataupun ditambah dengan kemudahan interface yang ditawarkan tidak akan banyak membantu perkuliahan secara daring apabila dari unsur brainware atau penggunanya yaitu mahasiswa dan dosen tidak pro aktif untuk mengunakannya (Suharyadi, 2013). Berhasil atau tidaknya seorang mahasiswa dalam e-learning tentu salah satu faktornya adalah adanya desain content yang lengkap dari dosen, maka disini mahasiswa harus bisa untuk bersahabat dengan dosen dan menikmati pembelajaran yang sudah disajikan. Dosen memberikan reward dan punishment dalam e-learning untuk meningkatkan kualitas mahasiswa dalam pembelajaran, sehingga mahasiswa akan mengikuti perintah dan anjuran dosen.

Menurut Nugroho (Koencoro, 2013) menjelaskan bahwa "Reward adalah ganjaran, hadiah, penghargaan atau imbalan yang bertujuan agar seseorang menjadi lebih giat lagi usahanya untuk memperbaiki atau meningkatkan kinerja yang telah dicapai." Sejalan dengan Nawawi (Tangkuman, 2015) bahwa "Reward dilakukan untuk menumbuhkan perasaan diterima (diakui) di lingkungan kerja, yang menyentuh aspek kompensasi dan aspek hubungan antara para pekerja yang satu dengan yang lainnya”. Dalam e-learning disini, dosen memberikan reward berupa tambahan nilai dan tambahan bintang untuk akses mempermudah soal UTS ataupun UAS. Tujuannya supaya mahasiswa menjadi semangat dan bersungguh-sungguh dalam melaksanakan e-learning, khususnya dalam memahami dan menguasai materi tersebut. Hal tersebut sejalan dengan teori dari (Handoko., 2013) mengemukakan beberapa "fungsi reward yaitu memperkuat motivasi untuk memacu diri agar mencapai prestasi, memberikan tanda seseorang yang memiliki kemampuan lebih, bersifat universal".

Dalam pelaksanaan e-learning, mahasiswa juga diberikan punishment, untuk mengimbangi reward supaya dalam diri mahasiswa akan ada pilihan harus menerima konsekuensi apak ketika tidak mengikuti $e$ learning. Rumiris (2013) menjelaskan bahwa "Ada tiga fungsi penting dari punishment yang berperan besar bagi pembentukan tingkah laku yang diharapkan yaitu: membatasi perilaku, penerapan punishment menghalangi terjadinya pengulangan tingkah laku yang tidak diharapkan. Punishmen juga bersifat mendidik, dan memperkuat motivasi untuk menghindarkan diri dari tingkah laku yang tidak diharapkan".

Dosen memberikan punishment dalam e-learning yaitu dengan mengurangi nilai tugas supaya mahasiwa menjadi termotivasi untuk tetap belajar dan memahami e-learning. Punishment lain bisa dengan menganggap ketidak hadiran apabila tidak mengikuti diskusi dengan baik, sehingga dengan punishment ini akan tercipta ruang diskusi yang efektif dalam e-learning karena mahasiswa pasti akan meluangkan waktunya untuk ikut berdiskusi dan memahami materi.

\section{Pengawasan}

Tercapainya tujuan e-learning bukan hanya tergantung kepada perencanaan dan pelaksanaan yang baik, melainkan juga tergantung pada pengorganisasian. Dalam hal ini dosen harus mampu mengawasi proses $e$ - 
learning demi ketercapaian pembelajaran dengan maksimal. Bukan berrarti dosen sudah membuat dan mendesain website e-learnig saja, namun harus tetap mengawasi mahasiswa apakah perencanaan dan pelaksanaan mahasiswa mampu mencapai tujuan yang dikehendaki atau tidak. Adanya kerjasama antara pimpinan perguruan tinggi yang menyediakan platform e-learning, dosen dan mahasiswa harus berjalan maksimal. Robbins dan Coulter (Hasanah, Yenny M. \& Husnul, 2019) menyatakan: "Management involves coordinating and overseeing the work activities of others so that their activities are completed efficiently and effectively". Manajemen melibatkan koordinasi dan mengawasi kegiatan kerja orang lain sehingga kegiatan mereka selesai dengan cara efisien dan ejektif.

Menurut Nisak dan Heri (2017), mengemukakan hasil penelitiannya bahwa "Pengorganisasiannya dengan metode mengajar yang melibatkan siswa untuk praktek langsung memahami materi, melibatkan semua siswa dalam memecahkan masalah dan mengkaitkan materi dalam kehidupan seharihari dan memanfaatkan IT dengan youtube serta guru tidak 'patah arang' dalam membantu siswa yang kesulitan". Sejalan dengan teori tersebut, dosen dalam e-learning untuk mengoordinasi dan mengawasi proses pembelajarannya yaitu dengan melibatkan media lain selain website resmi perguruan tinggi adalah media youtube, zoom, classroom, grup whatsapp.

Media-media sebagai pembantu dan penguat untuk bahan diskusi ini menjadi memudahkan mahasiswa dalam e-learning. Sebagai contoh dalam zoom meeting, mahasiswa bisa melakukan komunikasi dua arah, bisa berdiskusi dan tanya jawab langsung seperti tatap muka namun online. Media zoom menjadi sebuah trend dikalangan pendidikan, karena paling mudah akses dan menyesuaikan kuota dan waktu sesuai dengan keinginan dosen dan mahasiswa. Alternatif lain untuk melanjutkan diskusi adalah dengan membuat grup sementara melalui whatsapp atau classroom sehingga memudahkan mahasiswa ketika ingin menanyakan solusi atau permasalahan yang belum terpecahkan saat di zoom atau website.

Memang benar adanya bahwa $e$ learning ini atau media zoom, classroom dan whatsapp juga bisa di akses melalui handphone (HP) pribadi, sehingga dalam keefektifan akan menjadi lebih mudah. Jika memang mahasiswa atau dosen sedang ada pekerjaan lain dan laptop tidak bisa digunakan, maka semua platform di atas bisa memakai HP. Tidak ada alasan lain mahasiswa untuk tidak mengikuti e-learning jika tidak mempunyai leptop, karena semua bisa di akses melalui HP. Hanya disini yang menjadi kendala adalah harus menyediakan kuota internet yang memadai. Suheri (2020) memaparkan dalam jurnalnya bahwa "Dengan adanya aplikasi zoom meeting dan google classroom untuk media pembelajaran secara daring. Bagi sebagian orang Indonesia aplikasi zoom meeting dan google classroom mungkin masih dianggap baru. Penggunaan aplikasi zoom meeting dan google classroom dapat digunakan di smartphone. Hanya saja, saat diaplikasikan pada sesuatu yang baru dan bersifat pengajaran serta pembelajaran, tentu belum semua dapat mencernanya dengan baik". Evaluasi

Evaluasi dosen dalam proses e-learning terkait mahasiswa dilakukan dengan mendesain suatu test diagnostic dan tes daya serap, sebagai pretest dan post test. Ini akan menjadi indicator ketercapaian mahasiswa dalam pemahaman materi. Adanya tugas mandiri setiap pertemuan yang didesain dengan soal terbuka untuk meningkatkan higher order thingking skill (HOTS) mahasiswa. Dengan adanya tes dan tugas mandiri tersebut maka mahasiswa akan terlihat kemampuan sebelum dan sesudah menerima pembelajaran online. Meskipun dua tes tersebut bukan satu-satunya alternative dalam mengevaluasi ketercapaian mahasiswa, namun alternative lain bisa juga dengan 
mengevaluasi konteks, input, proses dan outputnya dalam desain website yang dibuat dosen. Kekurangan atau perbaikan dalam memaksimalkan konten e-learning dalam website harus selalu dilakukan, adanya inovasi dari dosen juga harus diupayakan.

Evaluasi memiliki makna yang berbeda dengan penilaian, pengukuran maupun tes. Stufflebeam dan Skinkfield (Widoyoko, 2013) menyatakan bahwa "Evaluation is the process og delenating, obtaining, and providing descriptive and judgmental information about the worth and merit of some object's goals, design, implementation, and impact in order ti guide decision making, serve needs for accountability, and promote understanding of the involved phenomena". Sejalan dengan Fitzpatrick, et al (2011) menyatakan bahwa "Definition of evaluation is "to determine or fix the value of: to examine and judge." Scriven defined evaluation as judging the wroth or merit of something. Define evaluation as the identification, clarification, and application of defensible to criteria to determine an evaluation object's value (wroth or merit) in relation to those criteria".

Pernyataan tersebut memberikan pengertian bahwa fungsi dari evaluasi adalah memberikan informasi yang valid dan dapat dipercaya mengenai kinerja kebijakan, yaitu seberapa jauh kebutuhan, nilai dan kesempatan yang telah dicapai melalui tindakan pelayanan publik. Evaluasi juga memberikan sumbangan pada klarifikasi dan kritik terhadap nilai-nilai yang mendasari pemilihan tujuan dan target, nilai diperjelas dengan mendefenisikan dan pengoperasian tujuan dan target. Nilai juga dikritik dengan menanyakan secara sistematis kepantasan tujuan dan target dalam hubungan dengan masalah yang dituju yang dapat menganalisis alternatif sumber nilai.

Dalam website yang didesain oleh dosen sudah di ujicobakan selama dua semester atau satu tahun untuk pembelajaran online. Hasil mahasiswa bisa dilihat dari nilai mahasiswa dalam mengerjakan soal dengan waktu yang ditentukan, dan hasil meningkat ketika website di desain secara lengkap. Ini sejalan dengan model CIPP dalam evaluasi program, yang dicanangkan oleh Stuffebeam (1965), yaitu " "The CIPP model is based on the view that the most important purpose of evaluation is not to prove, but to improve". Konsep evaluasi CIPP tersebut menawarkan bahwa tujuan penting evaluasi adalah bukan untuk membuktikan, tetapi juga untuk memperbaiki. CIPP dapat diterapkan dalam berbagai bidang, seperti, pendidikan, manajemen, perusahaan dan sebagainya. Dalam bidang pendidikan Stufflebem (1965) menggolongkan sistem pendidikan yaitu Context, Input, Process, dan Product.

Stufflebeam (1965) memaparkan evaluasi konteks, sebagai berikut: "Context evaluation assess needs, problems, assets and opportunities to help decision makers define goal and priorities and to help relevant user judge goals, priorities, and outcome". Evaluasi konteks dimaksudkan untuk menilai kebutuhan, masalah, asset dan peluang guna membantu pembuat kebijakan menetapkan tujuan dan prioritas, serta membantu kelompok pengguna lainnya untuk mengetahui tujuan, peluang dan hasilnya.

Tabel 2. Evaluasi Pembelajaran CIPP pada e-learning Website.

Context

Dalam konteks disini, isi dari masing-masing fitur seperti materi, video, forum diskusi dan jurnal untuk menunjang e-learning harus selalu di inovasi secara terus menerus. Keterbaruan dari referensi dan sumber dalam pengisian fitur desain tersebut harus selalu disesuaikan dengan kebutuhan saat ini.

\section{Input}

Untuk evaluasi input, dosen menambahkan fitur dalam website e-learning secara bertahap, yaitu dengan menambahkan tes diagnostic, tes daya serap dan tugas mandiri di setiap sub bab per pertemuan. 
Process

Dalam proses e-learning, banyak mahasiswa yang menanyakan mengenai implementasi dari materi yang diajarkan, oleh karena itu ada proses penambahan juga dalam hal tautan eksternal, berupa jurnal dan informasi berita dengan tujuan untuk meningkatkan pemahaman kepada mahasiswa.

\section{Product}

Evaluasi product disini adalah mengenai hasil belajar mahasiswa setelah mahasiswa diberikan fitur desain yang lengkap pada e-learning. Terbukti selama satu semester uji coba desain, pemahaman dan hasil belajar mahasiswa meningkat.
Kegiatan evaluasi masukan (input evaluation) bertujuan untuk membantu mengatur keputusan, menentukan sumbersumber, alternatif apa yang akan diambil, apa rencana dan strategi untuk mencapai kebutuhan, dan bagaimana prosedur kerja untuk mencapainya. Informasi dan data yang terkumpul dapat digunakan untuk menentukan sumber dan strategi dalam keterbatasan yang ada. Komponen evaluasi masukan meliputi: (1) sumber daya manusia, (2) sarana dan peralatan pendukung, (3) dana anggaran, dan (4) berbagai prosedur dan aturan yang diperlukan.

Evaluasi proses dirumuskan oleh Stufflebeam sebagai berikut: "a process evaluation is an ongoing check on a plan's implementation plus documentation of the process, including changes in the plan as well as key. Artinya sebuah evaluasi proses merupakan pemeriksaan sedang berlangsung pada pelaksanaan rencana serta dokumentasi proses, termasuk didalamnya perubahan dalam rencana serta ketidaksesuaian kunci, dan/atau eksekusi prosedur tertentu.

Terakhir adalah evaluasi produk merupakan penilaian yang dilakukan untuk mengukur keberhasilan dalam pencapaian tujuan yang telah ditetapkan data yang dihasilkan akan sangat menentukan apakah program diteruskan, dimodifikasi atau dihentikan. Dalam hal ini desain yang dibuat dosen dalam e-learning akan diukur ketercapaiannya, dengan indicator ketercapaian adalah pemahaman dan nilai mahasiswa dalam mata kuliah tersebut.

\section{SIMPULAN DAN SARAN}

Hasil penelitian ini menunjukkan bahwa strategi manajemen dosen, meliputi berikut ini

1. Perencanaan, yaitu menyusun rencana pembelajaran pada website e-learning, dengan sub tampilan RPS, capaian pembelajaran, tes diagnostic (pre-test), materi modul, video pembelajaran, tautan jurnal terkait materi, forum diskusi, tugas dan tes daya serap (post test).

2. Pelaksanaan, dengan intensitas mahasiswa pada forum diskusi untuk focus pada bagaimana menyelesaikan permasalahan materi (reward and punishment) dengan memahami modul dan video.

3. Pengawasan, yaitu dengan memanfaatkan waktu e-elarning yang disepakati, melakukan kontroling melalui media zoom, telefon conference dan grup whatsapp untuk mengetahui keaktifan dan ketercapaian mahasiswa dalam e-learning.

4. Evaluasi, dengan melakukan tes diagnostic dan tes daya serap sebagai indicator ketercapaian mahasiswa dalam menerima materi e-learning, kemudian dilanjutkan dengan tugas mandiri dengan pertanyaan terbuka yang meningkatkan HOTS (higher order of thinking skill). Evaluasi dalam memaksimalkan konten e-learning dalam website dilakukan dengan CIPP (context, input, process, output) agar inovasi dari dosen selalu meningkat.

\section{DAFTAR PUSTAKA}

Abiola, T. (2015). Psychometric assessment of the Wagnild and Young's resilience scale in Kano, Nigeria. BMC Research Notes, 4(1). 
Blackwell CK, Lauricella AR, W. (2016). Computers \& Education Factors in $\mathrm{fl}$ uencing digital technology use in early childhood education. Educational Technology Publications.

Clark, R. C., \& Mayer, R. E. (2003). E-learning And The Science of Instruction. CA: Jossey-Bass.

Fitzpatrick, J.L., Sanders, J.R., \& Worthen, B. . (2011). Program evaluation: Alternative approaches and practical guidelines (4thed.). Pearson Education, Inc.

Ghirardini, B. (2011). E-learning Methodologies: A Guide for Designing and Developing E-learning Courses. Food and Agriculture Organization of the United Nations.

Handoko. (2013). Pengantar Manajemen, Edisi Kedua, Cetakan Ketigabelas. BPFE.

Hasanah, Yenny M. \& Husnul, N. R. (2019). Strategies In Alleviating Gepeng (Homeless People And Beggars) In Jabodetabek. https://proceedings.iaipdnganjuk.ac.id/index.php/icoleess/article /view/41.

Husnul, Nisak, R. . (2017). Manajemen Kelas dalam Pembelajaran Matematika di SMA Negeri Yogyakarta. Jurnal Akuntabilitas Manajemen Pendidikan. https://doi.org/https://doi.org/10.21831/ amp.v5i2.15655.

Jethro, O. O., Grace, M. A., \& Thomas, K. A. (2012). E-learning and its effects on teaching and learning in a global age. International Journal of Academic Research in Business and Social Sciences. International Journal of Academic Research in Business and Social Sciences, 2(1), 203-210.

Kemenristek, D. (2018). Pengembangan Iptek dan Pendidikan Tinggi di Era Revolusi
Industri 4.0. Rakernas 2018: Siaran PERS No. 04/SP/HM/BKKP/I/2018.

Koswara. (2016). E-learning, Sejarah Perkembangannya, Dan Hubungan Dengan Disiplin Ilmu Lainnya. Media Cetak.

Pannen, P. (2014). E-learning Di Perguruan Tinggi Belum Terinisiasi Sistematis. http://kopertis3.or.id/v2/wpcontent/uploads/Paulina-PannenKebijakan-PJJ-dan-E-learning.pdf

Putranto, A. (2014). Penggunaan Tablet Di Binus Online Learning. Information Systems Department, School of Information Systems, Binus University. https://media.neliti.com/media/publicat ions/166076-ID-penggunaan-tablet-dibinus-online-learni.pdf

Rumiris, S. (2013). Pengaruh Reward dan Punishment Terhadap Disiplin Kerja Karyawan pada PT. Perkebunan Nusantara III Rambutan. JURNAL ILMIAH BUSSINESS PROGRESS, 1(01), 17-26.

Stufflebeam, D. L. (1965). Toward A Science of Educational Evaluation. Educational Technology Publications.

Sugiyono. (2012). Memahami Penelitian Kualitatif. Alfabeta.

Sugiyono. (2017). Statistika Untuk Penelitian. Alfabeta.

Suharno. (2018). Prinsip-Prinsip Dasar Kebijakan Publik. UNY Press.

Suharsimi, A. (2016). Prosedur Penelitian Suatu Pendekatan Praktik. PT. Rineka Cipta.

Suharyadi, A. (2013). Implementasi ELearning Di Fakultas Ilmu Pendidikan Universitas Negeri Yogyakarta. Hanata Widya, 2(3). 
Kelola: Jurnal Manajemen Pendidikan, Vol. 8, No. 1, Januari-Juni 2021

Suheri. (2020). Animasi Multimedia Pembelajaran. Elec Media Komputindo.

Sukarna. (2011). Dasar Dasar Manajemen. Mandar Maju.

Tangkuman. (2015). Penilaian Kinerja, Reward, Dan Punishment Terhadap Kinerja Karyawan pada PT. Pertamina
(Persero) Cabang Pemasaran Suluttenggo. Jurnal Emba, 3(2), 884895.

Widoyoko, S. E. . (2013). Evaluasi Program Pembelajaran: Panduan Praktis Bagi Pendidikan Dan Calon Pendidik. Pustaka Pelajar. 